ence of chronic diseases in the cadets overall effect on the level of vitamin $D(p=0.025)$, but this is not due to nosological forms $(p=0,189>0.05)$. From the bone-joint system, there are differences in the levels of vitamin $D$ at $5 \%$ level of significance, with low levels of vitamin D observed in the cadets with the chest deformity and flat feet. Thus, there is a contribution to an insufficient level of vitamin D are contributing factors such as the combination of in the body available virus - bacterial infection on the background of chronic pathology of gastrointestinal tract and disorders KSS-71,4\%. It has the value of summer holiday of teenagers in areas of high solar insolation resulting in increased and even in winter was significantly higher than in adolescents, the vacation of which took place in the zone of low insolation(p<0.001). Influenced by and taking multivitamins which include prophylactic dose of cholecalciferol (400-500ME) Alphabet, and Vitrum Duovit in contrast to the group with low vitamin D and adolescents did not take multivitamins(p<0.001).

The analysed results indicate a high frequency of failure and deficiency of cholecalciferol in the Amur region in children $15-17$ years of $86.6 \%$ with a mean level of vitamin $25(\mathrm{Oh}) \mathrm{D}=26,74 \pm 0,81 \mathrm{ng} / \mathrm{ml}$.

Conclusion. To prevent low vitamin D level of adolescents is necessary to study $25(\mathrm{OH}) \mathrm{D}$, its correction and control, taking into account risk factors for developing deficiency of vitamin D. Prophylactic administration of vitamin $\mathrm{D}$ should continue, and adolescent children year-round, given the low solar insolation, with the use of vitamin d compounds.

\title{
Literature
}

1. Holick M. F. Vitamin D deficiency. N. Engl.J. Med. 2007; 357:266-281.

2. Zakharova I. N., Maltsev S. V., Borovik T. E., etc. / Insufficiency of vitamin D in young children in Russia: results of multicenter cohort studies SPRING (2013-2014)//Issues of modern Pediatrics. 2014. Vol. 13. No. 6. P. 30-34.

3. Zakharova I. N., Maltsev S. V., Borovik T. E., etc. results of a multicenter study "Rodnichok" for the study of vitamin D deficiency in children of early age// Pediatrics. 2015. T. 94. No. 1. P. 62-67.

4. Borisenko E. P., Romantsova E. B., A. F. Babcia /Features D-deficient States in children living in the Amur region//Actual problems of health of children and adolescents: a compilation of scientific articles to the 85th anniversary DUGME: Khabarovsk: Publishing house DUGA, 2015. S. 21-27.

5. Vitebsk V. A., Smirnova E. G., Ilyin A. V. Vitamin D and indices of calcium-phosphorus metabolism in children living in an average strip of Russia, in the period of maximum insolation. Osteoporosis and osteopathy. 2010; $2: 4-9$.

6. Smirnova G. E., Vitebsk A. V., Shmakov N. And. The role of vitamin D in the development of the child's body and correction of its deficit. Current concepts]. App Pediatrics. 2010;34: 7-12.)

7. Heaney, R. P. Assessing vitamin D status. Curr. Opin. Clin. Nutr. Metab. Care. 2011; 14 (5): 440-444.

8. Brown AJ, Dusso A, Slatopolsky E. Vitamin D. Am. J. Physiol. Renal. Phisiol. 1999; 277: F157-F175.

9. Hayes CE, Nashold FE, Spach KM, Pedersen LB. The immunological functions of the vitamin D endocrine system. Cell Mol. Biol. (Noisy-le-grand). 2003; 49 (2): 277-300.

10. Maydannyk V. G. Rickets in children: modern aspects. Nizhyn: Aspect-Polygraph, 2006: 21-22, 26-31.

11. Modern Novikov P. V. rickets: classification, methods of diagnosis, treatment and prevention: a Handbook for physicians. M.: MNIIP and DH, 2007: 12-25.

12. Zakharova I. N., Korovina N. And., Dmitriev, Y. A. //Pediatrics//2010-c68-72.

13. Gromova O. A., Torshin I. Yu. Vitamin D is changing pradigm//Under the editor. Acad.RAS E. I. Guseva, Professor Zakharova I. N.// Moscow 2015.-S. 373-378.

DOI: 10.22448/AMJ.2016.15-16.23-24

UDC 637.514.92

\section{SOY - FROM ANCIENT BEANS TO MODERN SOY FOODS}

Borodin E.A., Shtarberg M.A., Feoktistova N.A., Pamirsky I.E.

\section{Amur State Medical Academy, Blagoveshchensk, Russia}

For Asia people Soy is a traditional food. Considering its role the leading specialist in the study of healthy effects of soy foods M. Messina wrote: "In China the word for soybean is ta-tou, which means "greater bean. It is not surprising to give the importance to soybeans because in Asian culture, they were both as a food and a medicine" (Messina, 1995). There are a lot of oriental soy-foods, such as soy milk - Doujiang (China), Tonyu (Japan), bean curd - Tofu (Japan), Dòufu (China), fermented beans - Natto (Japan), fermented bean paste - Miso (Japan), Doubanjiang or Douchi (China), Doenjang (Korea), soy sauce - Chiyou/siyau (China), Shōyu (Japan) and many others. In the West, soybeans for many years were best known for their high protein content. The healthy effects of Soy foods are being increasingly recognized in the USA, Europe and Russia only within the last decades mainly because of the results of epidemiological studies revealing the low incidence of pros- 
tate and breast cancer and lower blood cholesterol in people from Asia countries. An impressive amount of research on Soy has evaluated the role of Soy foods in reducing chronic disease risk. Eight International Symposia on the Role of Soy in Health Promotion and Chronic Disease Prevention and Treatment were held within 1995-2009. The new Western style Soy foods were created and marketed as healthy foods. Soybeans were brought to Russia from northern-eastern China and nowadays are planted in the Amur Region, Altai region and Kuban territory near the Black Sea.

We begin the study of Soy phospholipids as membrane stabilizing drugs, capable to prevent and eliminate the damages of biological membranes caused by free radical oxidation of lipids (Archakov et al, 1982, 1983; Borodin et al., 1985) and to extract the excess of cholesterol from plasma cell membranes (Borodin et al., 1981, 1984; Borodin \& Lopukhin, 1987) in the 80-th of the former century.

In the last decades we focused on the antioxidants of Soy (Borodin et al., 2000, 2012), cholesterol lowering effect of consumption of Soy protein foods (Borodin et al., 2009, 2011) and on the possibility of use of Soybean trypsin inhibitor for the development of new protease inhibitor drug (Pamirsky et al., 2012; Borodin et al., 2013). Our study of the effects of soy protein isolate and casein on blood lipids and glucose in Russian adults with moderate hyperlipidemia (Borodin et al., 2009) was cited by M. Messina, who wrote: "The first study was conducted by Russian investigators and utilized a cross over design. Twenty-eight middle aged hypercholesterolemic subjects ( 19 females and 9 males aged $50+/-2$ y) consumed diets that contained cookies providing either $30 \mathrm{~g}$ isolated soy protein or $30 \mathrm{~g}$ skimmed milk protein. After two months, non-HDL-cholesterol (total cholesterol minus HDL-cholesterol) decreased $11 \%$ from 223 to $201 \mathrm{mg} / \mathrm{dL}$ ( $\mathrm{p}=0.0023$ ) in the soy group whereas there was no change in the control” (Messina, 2010).

\section{Literature}

1.Archakov A.I. Borodin E.A., Davidov D.R., Karyakin A.V \& Borovyagin V.L. Random distribution of NADH-specific flavoprotein and cytochrome P-450 in liver microsomes. Biochem. Biophys. Res. Commun., 1982, V.109, pp. 832-840.

2.Archakov A.I., Borodin E.A., Dobretsov G. E., Karasevich E.I. \& Karyakin A.V The influence of cholesterol incorporation and removal on lipid bilayer viscosity and electron transfer in rat-liver microsomes. Europ. J. Biochem., 1983, V.134, pp. 89-95.

3.Borodin E.A., Sergienko V.I., Khalilov E.M., Archakov A.I., Lopukhin Yu.M. Isolation of cholesterol from erythrocyte shadows, microsomes and blood plasma using specific sorbent and phospholipid liposomes. Biomedicinal Chemistry (Moscow). 1981. No. 2. pp. 235-238.

4.Borodin E.A., Markin S.S., Archakov A.I., Lopukhin Yu.M. Removal of cholesterol from erythrocyte ghosts by phospholipids. Biomedicinal Chemistry (Moscow). 1984. Vol. 30. No. 2. pp. 75-77.

5.Borodin E.A., Archakov A.I. \& Lopukhin Yu.M. Theoretical basis for the use of unsaturated phospholipids for the restoration of structure and functions of damaged biological membranes. Vestnik of the Russia Academy of Medical Sciences (Moscow). 1985, N.3, pp.84-90.

6.Borodin E.A. \& Lopukhin Yu.M. Physicochemical basis for phospholipid therapy in the management of cholesterosis. In "Soviet Medicine Reviews. Section B. Physicochemical Aspects of Medicine, V.1, 1987, pp.205-253. Harwood Academic Publishers GmbH, United Kindom, London.

7.Borodin E.A., Aksenova T.V. \& Anishchenko N.I. Soy fods. The new role. Vestnik of FEBRAS (Vladivostok). 2000. No.5. pp. 72-85.

8.Borodin E.A., Menshikova I.G., Dorovskikh V.A., Feoktistova N.A., Shtarberg M.A., Yamamoto T., Takamatsu K., Mori H.\& Yamamoto S. Effects of soy protein isolate and casein on blood lipids and glucose in Russian adults with moderate hyperlipidemia. Journal of Nutritional Sciences and Vitaminoligy. 2009. V. 50, pp. 492-497.

9.Borodin E.A., Menshikova I.G., Dorovskikh V.A., Feoktistova N.A., Shtarberg M.A., Yamamoto T., Takamatsu K., Mori H.\& Yamamoto S. Antioxidant and Effects of Soy Bean Trypsin Inhibitor on Hemostasis. In: Soybean and Health. (Ed.by Hany A. El-Shemy). In-Tech, Croatia, 2011, pp. 407-424.

10.Borodin E.A., Pamirsky I.E., Shtarberg M.A., Dorovskikh V.A, Korotkikh A.V., Tarumizu C., Takamatsu K. \& Yamamoto S. Effects of Soy Bean Trypsin Inhibitor on Hemostasis. In: Soybean - A Review. (Ed.by Hany A. El-Shemy). In-Tech, Croatia, 2013, pp. 495-512.

11. Messina M. Modern Applications for an Ancient Bean: Soybeans and the Prevention and Treatment of Chronic Disease. J. Nutr. 1995. Vol. 125. pp. 567S-569S.

12.Messina M. Letter to the Editor. Menopause (New York, N.Y.) 2010. Vol.17. Issue 6. p.1206.

13.Pamirsky I., Borodin E. \& Shraberg M. (2012) Regulation of proteolysis by plant and animal inhibitors. LAP Lambert Academic Publishing. 105p. ISBN/ISSN:978-3-8473-3135-3. 